\title{
Dowry Demand and other Risk Factors for Intimate Partner Violence Against Adolescent Girls: A Cross- sectional Study in India
}

\section{Shobhit Srivastava}

International Institute for Population Sciences

Pradeep Kumar

International Institute for Population Sciences

Manideep Govindu

Karnataka Health Promotion Trust

Muhammad T ( $\square$ muhammad@iips.net)

International Institute for Population Sciences

\section{Research Article}

Keywords: Dowry, decision making, violence, married adolescents, UDAYA

Posted Date: January 8th, 2021

DOI: https://doi.org/10.21203/rs.3.rs-139794/v1

License: (c) (i) This work is licensed under a Creative Commons Attribution 4.0 International License.

Read Full License 
Dowry demand and other risk factors for intimate partner violence against adolescent girls: A cross-sectional study in India

\section{Shobhit Srivastava}

Affiliation: Ph.D. Research Scholar, Department of Mathematical Demography \& Statistics, International Institute for Population Sciences, Mumbai, India

Email: shobhitsrivastava889@gmail.com

ORCID: 0000-0002-7138-4916

\section{Pradeep Kumar}

Affiliation: Ph.D. Research Scholar, Department of Mathematical Demography \& Statistics, International Institute for Population Sciences, Mumbai, India

Email: pradeepiips@yahoo.com

ORCID: 0000-0003-4259-820X

\section{Manideep Govindu}

Affiliation: Researcher at Karnataka Health Promotion Trust, Bengaluru

Email: manideepgovindu2@gmail.com

\section{Muhammad T.}

Affiliation: Ph.D. Research Scholar, Department of Population Policies and Programmes, International Institute for Population Sciences, Mumbai, India

ORCID: 0000-0003-1486-7038

(Corresponding Author)

Email: $\underline{\text { muhammad@iips.net }}$ 


\title{
Dowry demand and other risk factors for intimate partner violence against adolescent girls: A cross-sectional study in India
}

\begin{abstract}
Background: Violence against women is considered a fundamental violation of women's human rights. According to the World Health Organization, worldwide one-third of women experience some form of intimate partner violence. The present study aims to examine the association of dowry demand and other associated risk factors with physical, sexual, or emotional violence against married adolescent girls in two major states of India by using large representative data.
\end{abstract}

Methods: Understanding the lives of adolescents and young adults (UDAYA) project survey data was used for this study. The effective sample size for the study was 4893 married adolescent girls. Descriptive statistics along with bivariate analysis was performed to examine the preliminary results. For analyzing the association binary logistic regression method was used.

Results: The prevalence of emotional, physical, and sexual violence was $28.6 \%, 22.9 \%$, and $26.1 \%$ among married adolescent girls respectively. About $44 \%$ of married adolescent girls experienced any type of violence (emotional/physical/sexual). The prevalence of violence was significantly higher among girls who reported that dowry was demanded by their husbands (emotional-54\%, physical-42.1\%, sexual-39.6\%, and any violence-68.4\%). Results show that the likelihood of any violence was 3.66 times more likely among adolescent girls who reported that dowry was demanded by their husbands than their counterparts [OR: 3.66; CI: 3.06-4.37]. Other risk factors for intimate partner violence among adolescents included justifying wife-beating, low decision-making power, having a paid job, and longer marital duration. 
Conclusion: The results presented in this study suggest that policies that ensure equal inheritance and property rights for women and programs that help adolescent girls retain equal power and say in their family may be necessary to reduce their vulnerability to domestic violence.

Keywords: Dowry; decision making; violence; married adolescents; UDAYA 


\section{Background}

Violence against women is considered a fundamental violation of women's human rights (WHO, 2010). According to the World Health Organization, worldwide one-third of women experience some form of intimate partner violence (WHO, 2015). Dowry as an aspect of marriage transactions is recognized as a key factor that underpins violence against women (Rastogi \& Therly, 2006). Even though dowry is prohibited in India under the Dowry Prohibition Act 1961 and subsequent Sections 304B and 498A of the Indian Penal Code, it remains a common practice (Anitha, Yalamarty, \& Roy, 2018).

The stronghold of gender inequality in society makes the dowry demands of the man who has agreed to take care of the daughter an obligation to the bride's family (Rudd, 2001). Further, motives behind the predominant dowry system in South Asia both in price and bequest form, are heterogeneous and primarily depend on bride or groom characteristics (Arunachalam \& Logan, 2016). Dowry, on the other hand, has been implicated in many forms of gender-based violence such as son preference and sex-selective abortions (Purewal, 2018; Sabarwal, McCormick, Subramanian, \& Silverman, 2012; Sen, 2003), and several forms of sexual and emotional violence (Priya et al., 2014). Additionally, a recent study in India suggests that the price of gold at the time of marriage and the amount of gold a woman receives as dowry were significant predictors of domestic violence (Menon, 2020). Some of the earlier studies from India found the inadequate or delayed payment of dowry as important reasons for the perpetration of violence by a husband or members in-laws (Bloch \& Rao, 2002; Pallikadavath \& Bradley, 2019; Sharma, Harish, Gupta, \& Singh, 2005). There are also reports of domestic violence against women whose dowries were deemed insufficient by their husbands or by husbands' families (V. Jeyaseelan et al., 2015). 
However, due to the increase in female schooling and rapid changes in gender roles, there is a positive impact on marriage practices in India where less significance is given to parents in arranging marriages for their children (Dommaraju, 2009). Some characteristics of husband and families influence a woman's likelihood of being victimized. Husband's inability and lack of resources to meet the family's needs can cause stress and ultimately lead to frustration (Li, Bloom, Herbell, \& Bullock, 2020). Violence perpetrated by husbands of married adolescents can be a possible response to this frustration. Family-level characteristics which are found to be the predictors of intimate partner violence include family's socioeconomic condition and decision making power and the role of women in the family (Koenig, Ahmed, Hossain, \& Alam Mozumder, 2003). It is documented that women's lack of autonomy could be a major determinant of the victimization of domestic violence (Banerjee, 2014).

A study by Donta et al found that women empowerment that is measured by decision-making power, freedom of movement, and not justifying wife-beating was less likely to be a risk factor of domestic violence (Donta, Nair, Begum, \& Prakasam, 2016). Also, it is revealed that the decline in the male-female wage gap may reduce domestic violence by improving the intra-household bargaining power of women (Aizer, 2010). On the other hand, the patriarchal gender relations and women's subordinate status after the marriage as new brides create a conducive context for violence in their husband's home (Gangoli \& Rew, 2011). A crosscountry analysis of attitudes towards wife-beating in Asia brought out that acceptance of wife-beating among women was highest in India (Rani \& Bonu, 2009). Other studies in India show that a large amount of violence is perpetrated by the wider household, including female in-laws (Panchanadeswaran \& Koverola, 2005; Ragavan \& Iyengar, 2017). Further, some of the socioeconomic and demographic characteristics of women such as urban residence, older age, lower education, and lower family income were also associated with the occurrence of domestic violence (Bontha V. Babu \& Kar, 2009). 
India has an alarming trend of dowry deaths that sees more than 7000 women die every year as a result of harassment over dowry (NCRB, 2019). The highest number of dowry deaths, and dowry death rates, were recorded in the two northern states of Uttar Pradesh and Bihar (NCRB, 2014). However, little is known about the nature of the problem and women's experiences of forced dowry during and following their marriage resulting in some form of violence. Since there is scant research on this subject, we in this study, aim to examine the association of dowry demand and other associated risk factors with physical, sexual, or emotional violence against married adolescents in two major states of India by using a large representative data.

\section{Data and methods}

\section{Data}

Understanding the lives of adolescents and young adults (UDAYA) project survey data was used for this study. The survey was conducted in two Indian states namely, Uttar Pradesh and Bihar in 2016 by the Population Council under the guidance of the Ministry of Health and Family Welfare, Government of India. The UDAYA collected detailed information on family, media, community environment, assets acquired in adolescence, and quality of transitions to young adulthood indicators. The survey adopted a multi-stage systematic sampling design to provide the estimates for states as a whole as well as the urban and rural area of the states. The sample size for Uttar Pradesh and Bihar was 10,350 and 10,350 adolescents aged 10-19 years, respectively. The required sample for each sub-group of adolescents was determined at 920 younger boys (10-14 years), 2,350 older boys (15-19 years), 630 younger girls, 3,750 older girls, and 2,700 married girls in both states. The effective sample size for the present study is 4893 married adolescent girls.

\section{Variable description}




\section{Outcome variable}

Emotional violence was recoded as if the husband humiliate the respondent in front of others coded as 1 'yes' and 0 'no,' otherwise. Physical violence was recorded as 1 'yes' if the husband ever slapped, twisted or pulled hair, pushed/shook or throe something, kicked dragged beaten, burnt on purpose, attacked with a knife to the respondent in last 12 months and 0 'no,' otherwise. Sexual violence was defined as 'yes' if the husband ever forced the respondent to have sex in the last 12 months and 'no'; otherwise. Any violence was recoded as 1 'yes' if the married girl experienced any type of violence (emotional/physical/sexual); otherwise 0 "no".

\section{Exposure variables}

Dowry demand by husbandwas recoded as no and yes. The variable was generated using the question "Anyone in husband family said that dowry/cash/ gift was too less or ever respondents husband family asked her to bring more cash/ gift/ dowry. Perception over wifebeating was recoded not justified and justified using the question 'is it right for a husband to beat his wife?". The decision about an adolescent girl going to work was recoded 'herself or jointly with others' and 'Other only'. The decision-making on household purchase was recoded as herself or jointly with others' and 'Other only'. Paid work in the last 12 months was recoded as "no" and "yes". Marital duration (in years) was recoded as less than one year, 2-3 years, and more than four years.

Age of the adolescent girls grouped into two categories: 15-17 years and 18-19 years. Education level was recoded as no education, 1-7 years, 8-9 years, and $10 \&$ above year. Place of residence was given in the survey as rural and urban. Caste was grouped as scheduled caste/scheduled tribe (SC/ST), OBC (Other Backward Class), and others. Religion was recoded as Hindu and non-Hindu. Wealth quintile was created based on household asset 
data on ownership of selected durable goods, including means of transportation, as well as data on access to several amenities. The variable was recoded into five equal quintiles as poorest, poorer, middle, richer, and richest.

\section{Statistical analysis}

Descriptive statistics along with bivariate analysis was done to examine the preliminary results. For analyzing the association between the binary outcome variable (violence experienced by married adolescent girls) and other explanatory variables binary logistic regression method was used. We termed adolescent girls aged 15-19 as late adolescents.

The equation for logistic distribution

$$
\ln \left(\frac{\pi}{1-\pi}\right)=\alpha+\beta_{1} X_{1}+\beta_{2} X_{2}+\beta_{3} X_{3} \ldots \ldots \beta_{n} X_{n}
$$

Where, $\beta_{0}, \ldots \ldots, \beta_{\mathrm{M}}$, are regression coefficients indicating the relative effect of a particular explanatory variable on the outcome variable. These coefficients change as per the context in the analysis in the study.

\section{Results}

Socio-demographic characteristics of married adolescent girls aged 15-19 years are presented in Table 1. About one-fourth of the sample population reported that dowry was demanded by their husband, and nearly 27 percent of the participants justified wife-beating. More than half of the adolescent girls decided herself/jointly with others about their work. Moreover, 42 percent of adolescent girls decided herself/jointly with others on the matters of household purchases. Only 11 percent of girls were having a paid job. A higher proportion of girls belonged to the 18-19 years age group and about one-fourth of married adolescent girls had 10 and above years of schooling. 
Percentage distribution of type of violence among married adolescent girls aged 15-19 years is presented in Table 2. The prevalence of emotional, physical, and sexual violence was $28.6 \%, 22.9 \%$, and $26.1 \%$ among married adolescent girls respectively. Moreover, about $44 \%$ of married adolescent girls experienced any type of violence (emotional/physical/sexual). The prevalence of violence (emotional-54\%, physical-42.1\%, sexual-39.6\%, and any violence$68.4 \%$ ) was significantly higher among girls who reported that dowry was demanded by their husbands. Similarly, married girls who justified wife-beating reported more violence (emotional-34.3\%, physical-29.5\%, sexual-36.2\%, and any violence-53.3\%). Moreover, there was a positive relationship between violence (each one) and the marital duration among adolescent girls. For instance, married girls faced more violence to increase the length of the marriage. Similarly, violence had a significant positive association with the educational level of girls and wealth index. Violence was more reported by girls who had no education and also those who belonged to the poorest family whereas it was lowest among girls who had 10 and above years of schooling and those who belonged to the richest families.

Estimates from logistic regression analysis for the type of violence among married adolescent girls aged 15-19 years are presented in Table 3. Results show that the likelihood of any violence was 3.66 times more likely among adolescent girls who reported that dowry was demanded by their husbands than their counterparts[OR: 3.66; CI: 3.06-4.37]. Moreover, girls who justified wife-beating were 56 percent more likely to face any violence compared to their counterpart [OR: 1.56; CI: 1.28-1.90]. Similarly, adolescent girls whose decisions about their work taken by others only had 34 percent higher odds of any violence than those who decided their work themselves/jointly with others [OR: 1.34; CI: 1.07-1.68]. The odds of any violence were 37 percent higher among adolescent girls whose decision on household purchase was taken by others compared to those who decided household purchase themselves/jointly with others [OR: 1.37; CI: 1.09-1.71]. Interestingly, the likelihood of any violence was 41 percent 
and 2.06 times more likely among adolescent girls whose marital duration was 2-3 years [OR: 1.41; CI: 1.19-1.66] and 4 years or more [OR: 2.06; CI: 1.60-2.64] respectively, compared to those whose marital duration was less than or equal to one year. Adolescent girls who had 10 and above years of education were 29 percent less likely to face any violence than girls with no education [OR: 0.71; CI: 0.57-0.89]. Similarly, adolescent girls who belonged to other caste groups were 41 percent less likely to face any violence compared to girls who belonged to SC/ST group [OR: 0.59; CI: 0.43-0.80].

\section{Discussion}

The fourth National Family Health Survey reported that more than 30 percent of women in India have been physically mistreated by their husbands or other family members (IIPS \& ICF, 2017). Dowry related issues could be one of the reasons for this mistreatment. The age-old custom of dowry and gifts for husband and in-laws is strongly related to increased violence against women in India (L. Jeyaseelan et al., 2007; V. Jeyaseelan et al., 2015; Kumar, Jeyaseelan, Suresh, \& Ahuja, 2005). Consistently, our results show that the married adolescent girls who reported that dowry was demanded by their husband during or after their marriage were more likely to experience partner violence. Contrary to our finding, a study in South India found that larger dowries reduce marital violence through their effect on increasing the economic resources of the marital household, enhancing the social status of the groom and his family (Srinivasan \& Bedi, 2007).

The results further show an association of perception over wife-beating by married adolescent girls, another key variable of interest in our study with experiencing partner violence. Consistent with previous studies (Donta et al., 2016; Koenig, Stephenson, Ahmed, Jejeebhoy, \& Campbell, 2006), it was found that a large proportion of the study sample justified wifebeating were more likely to report any type of partner violence. The finding indicates that 
married women in India who still hold onto gender norms and accept wife-beating as deep social learning have a higher likelihood of being the victims of partner violence and that often perpetuates the traditional sex-stereotyped roles in the society. Similarly, the power dynamics in the family and women's empowerment have a greater impact on women's status such that the chances of being mistreated are lower among women who are involved in the family's decision-making processes (G. R. Babu \& Babu, 2011). Consistently, the present study shows that married adolescent girls who decided alone or jointly with others on matters of going for work and household purchases were significantly more likely to experience any type of violence. In the process of empowering women, the study indicates that parents appear to be replacing property inheritance to their daughters by giving them alternative transfers in the form of higher dowries (Roy, 2015). This might have resulted in husbands and family in-laws of empowered women not perpetrating any violence.

Furthermore, it is shown that the employed women may have more domestic power and are more likely to be exposed to media, and their financial resources allow them to question traditional subordinate roles and practices (Malhotra \& Mather, 1997). A study in Uttar Pradesh found that women's participation in paid work and house ownership were significantly associated with a reduction in experiencing marital violence (Bhattacharyya, Bedi, \& Chhachhi, 2011). However, as far as paid work among married adolescent girls in the present study is concerned, the protective effect of women's employment on the violence that is shown in several past studies (Panda \& Agarwal, 2005; Rao, 1997), was not found in the present study. The analysis shows that adolescent girls who are engaged in paid work are significantly more likely to experience physical or sexual violence than their counterparts. The finding is similar to a study based on the National Family Health Survey which noted that because of being forthright against male dominance and better reporting of incidences of domestic violence, Indian working women have a higher likelihood of being victims of 
violence (Sahoo \& Raju, 2007). Again, women who are engaged in small business and farming and have a higher economic status than their husbands and are seen as having sufficient power to change traditional gender roles were at greater risk for experiencing partner violence (B. V. Babu \& Kar, 2010; Kaukinen, 2004; Koenig et al., 2003).

Marital duration is considered a proxy for compatibility in a marriage (Henning \& ConnorSmith, 2011). Also, the rates of ever-experiencing violence can be expected to rise with marital duration; because a longer marriage provides a longer period of exposure (Djamba \& Kimuna, 2008). In a previous study, it was shown as a potential risk factor of victimization of violence (Babu \& Kar, 2010). Considering the marital duration of the study participants, compared with adolescent girls who had been married for less than one year, those who were married for more than one year were more likely to be victims of any type of partner violence. This can be explained as women in an abusive relationship for a longer duration would be less bothered about social stigma and more open to admitting any domestic violence (Kimuna, Djamba, Ciciurkaite, \& Cherukuri, 2013). The results are in agreement with an earlier study in India which found that women married for five years and longer were more likely to be beaten by their husbands (Sahoo \& Pradhan, 2009).

Finally, evidence suggests that status and power discrepancies in owning resources and lack of education may be associated with increased domestic violence especially by men who hold traditional ideas about gender and believe that men should be the primary bread-winners for a family (Atkinson, Greenstein, \& Lang, 2005). A dearth of literature repeatedly found educational attainment and higher social status as major factors to reduce the likelihood of experiencing domestic violence in developed as well as developing countries (Ergin, Bayram, Alper, Selimoglu, \& Bilgel, 2008; Erten \& Keskin, 2018; Firestone, Harris, \& Vega, 2003; Simister \& Makowiec, 2008). The present study in concordance with this found that higher education and upper social class in the Indian caste hierarchy of married adolescent girls were 
protective factors against partner violence. The finding mirrors the feminist political theory, which holds that the maintenance of patriarchy and male social dominance over women is the primary contributor to abuse and lack of women's access to educational, economic, and political resources is a major factor that contributes to increased violence (Taft, Bryant-Davis, Woodward, Tillman, \& Torres, 2009).

The study has certain limitations. Due to the cross-sectional nature of the study, no causal relationships could be established. Another major limitation of the study is that all data were self-reported by married adolescent girls and therefore subject to recall and social desirability biases, particularly those that relate to the private realm, such as dowry demand by husband or in-laws and experiencing domestic violence. A large proportion not reporting dowry may be explained by the fact that many of them do not consider dowry as a repressive practice but a rightful share of their parents' inherited property (Anitha et al., 2018). Despite these limitations, the study sheds light on potential determinants of intimate partner violence in India and contributes to the existing literature on domestic violence because of its large population-based data.

\section{Conclusion}

The study findings facilitate policymakers and healthcare personnel to intervene more effectively with married adolescent girls who are at greater risk for victimization of violence. The results presented in this study suggest that policies that ensure equal inheritance and property rights for women and programs that help women retain equal power and say in their family may be necessary to reduce their vulnerability to domestic violence. To reduce the perpetration of violence by men, the health sector could also do much in terms of providing holistic and responsive care to the victims of violence, referral to appropriate legal and counseling agencies, and identification of the nature, extent, and determinants of the problem. 
The results also highlight the need for societal changes that will promote social structures that are less marred by domestic violence against married women. Further, programs on reproductive health must also address the socio-cultural gender-related norms that increase women's vulnerability to the victimization of violence. There is also a need to change the attitudes towards domestic violence and gender differentials in the household power dynamics through direct and proactive efforts. Empowering adolescent girls through education and improving their ability to find employment and better economic status in the future, along with increasing public awareness of issues related to human rights may help lower the prevalence of domestic violence.

\section{Declarations}

Ethics approval: The data is freely available in the public domain on request and the study has been approved by the Population Council Review Board, New Delhi. All methods were performed following the relevant guidelines and regulations.

Consent to participate: Informed consent has been taken from the participants in verbal and written forms.

Consent for publication: Not applicable

Availability of data and materials: The study utilizes a secondary source of data that is freely available in the public domain through:

https://dataverse.harvard.edu/dataset.xhtml?persistentId=doi:10.7910/DVN/RRXQNT.

The necessary ethical approval has been taken by the respective organizations involved in the data collection process.

Competing Interest: The authors declare that they have no competing interests.

Funding: Authors did not receive any funding to carry out this research. 
Author's Contribution: The concept was drafted by SS, PK, MG, and MT. PK and SS contributed to the analysis design. MT advised on the paper and assisted in paper conceptualization. MT, SS, PK, and MG contributed to the comprehensive writing of the article. All authors read and approved the final manuscript.

Acknowledgments: Not applicable 


\section{References}

Aizer, A. (2010). The gender wage gap and domestic violence. American Economic Review, 100(4), 1847-1859. https://doi.org/10.1257/aer.100.4.1847

Anitha, S., Yalamarty, H., \& Roy, A. (2018). Changing nature and emerging patterns of domestic violence in global contexts: Dowry abuse and the transnational abandonment of wives in India. Women's Studies International Forum, 69(May), 67-75. https://doi.org/10.1016/j.wsif.2018.05.005

Arunachalam, R., \& Logan, T. D. (2016). On the heterogeneity of dowry motives. Journal of Population Economics, 29(1), 135-166. https://doi.org/10.1007/s00148-015-0544-1

Atkinson, M. P., Greenstein, T. N., \& Lang, M. M. (2005). For Women , Breadwinning Can Be Dangerous : Gendered Resource Theory and Wife Abuse. Journal of Marriage and Family, 67(5), 1137-1148.

Babu, G. R., \& Babu, B. V. (2011). Dowry deaths: A neglected public health issue in India. International Health, 3(1), 35-43. https://doi.org/10.1016/j.inhe.2010.12.002

Babu, B. V., \& Kar, S. K. (2010). Domestic violence in Eastern India: Factors associated with victimization and perpetration. Public Health, 124(3), 136-148. https://doi.org/10.1016/j.puhe.2010.01.014

Babu, Bontha V., \& Kar, S. K. (2009). Domestic violence against women in eastern India: A population-based study on prevalence and related issues. BMC Public Health, 9, 1-15. https://doi.org/10.1186/1471-2458-9-129

Banerjee, P. R. (2014). Dowry in 21st-Century India: The Sociocultural Face of Exploitation. Trauma, Violence, and Abuse, 15(1), 34-40. https://doi.org/10.1177/1524838013496334

Bhattacharyya, M., Bedi, A. S., \& Chhachhi, A. (2011). Marital Violence and Women's 
Employment and Property Status: Evidence from North Indian Villages. World Development, 39(9), 1676-1689. https://doi.org/10.1016/j.worlddev.2011.02.001

Bloch, F., \& Rao, V. (2002). Terror as a Bargaining Instrument : A Case Study of Dowry Violence in Rural India. The American Economic Review, 92(4), 1029-1043.

Djamba, Y. K., \& Kimuna, S. R. (2008). Intimate partner violence among married women in Kenya. Journal of Asian and African Studies, 43(4), 457-469. https://doi.org/10.1177/0021909608091976

Dommaraju, P. (2009). Female Schooling and Marriage Change in India. Population, 64(4), 667-683. Retrieved from https://www.cairn-int.info/revue-population-2009-4-page667.htm?contenu=article

Donta, B., Nair, S., Begum, S., \& Prakasam, C. P. (2016). Association of Domestic Violence From Husband and Women Empowerment in Slum Community, Mumbai. Journal of Interpersonal Violence, 31(12), 2227-2239. https://doi.org/10.1177/0886260515573574

Ergin, N., Bayram, N., Alper, Z., Selimoglu, K., \& Bilgel, N. (2008). Domestic violence: A tragedy behind the doors. Women and Health, 42(2), 35-51. https://doi.org/10.1300/J013v42n02_03

Erten, B., \& Keskin, P. (2018). For better or for worse? Education and the prevalence of domestic violence in Turkey. American Economic Journal: Applied Economics, 10(1), 64-105. https://doi.org/10.1257/app.20160278

Firestone, J. M., Harris, R. J., \& Vega, W. A. (2003). The impact of gender role ideology, male expectancies, and acculturation on wife abuse. 26, 549-564. https://doi.org/10.1016/S0160-2527(03)00086-4

Gangoli, G., \& Rew, M. (2011). Mothers-in-law against daughters-in-law: Domestic violence 
and legal discourses around mother-in-law violence against daughters-in-law in India. Women's Studies International Forum, 34(5), 420-429.

https://doi.org/10.1016/j.wsif.2011.06.006

Heise, L. L., Raikes, A., Watts, C. H., Zwi, A. B., \& Dc, U. S. A. (1994). Violence Against Women : a Neglected Public Health Issue in Less Developed Countries. Social Science \& Medicine, 39(9). https://doi.org/https://doi.org/10.1016/0277-9536(94)90349-2

Henning, K., \& Connor-Smith, J. (2011). Why doesn't he leave? Relationship continuity and satisfaction among male domestic violence offenders. Journal of Interpersonal Violence, 26(7), 1366-1387. https://doi.org/10.1177/0886260510369132

IIPS \& ICF. (2017). National Family Health Survey (NFHS-4), 2015-16: India Report. Retrieved from http://rchiips.org/nfhs/nfhs-4Reports/India.pdf

Jeyaseelan, L., Kumar, S., Neelakantan, N., Peedicayil, A., Pillai, R., \& Duvvury, N. (2007). Physical spousal violence against women in India: Some risk factors. Journal of Biosocial Science, 39(5), 657-670. https://doi.org/10.1017/S0021932007001836

Jeyaseelan, V., Kumar, S., Jeyaseelan, L., Shankar, V., Yadav, B. K., \& Bangdiwala, S. I. (2015). Dowry demand and harassment: Prevalence and risk factors in India. Journal of Biosocial Science, 47(6), 727-745. https://doi.org/10.1017/S0021932014000571

Kaukinen, C. (2004). Status compatibility, physical violence, and emotional abuse in intimate relationships. Journal of Marriage and Family, 66(2), 452-471. https://doi.org/10.1111/j.1741-3737.2004.00031.x

Kimuna, S. R., Djamba, Y. K., Ciciurkaite, G., \& Cherukuri, S. (2013). Domestic Violence in India: Insights From the 2005-2006 National Family Health Survey. Journal of Interpersonal Violence, 28(4), 773-807. https://doi.org/10.1177/0886260512455867 
Koenig, M. A., Ahmed, S., Hossain, M. B., \& Alam Mozumder, A. B. M. K. (2003).

Women's status and domestic violence in rural Bangladesh: Individual- and communitylevel effects. Demography, 40(2), 269-288. https://doi.org/10.2307/3180801

Koenig, M. A., Stephenson, R., Ahmed, S., Jejeebhoy, S. J., \& Campbell, J. (2006). Individual and contextual determinants of domestic violence in North India. American Journal of Public Health, 96(1), 132-138. https://doi.org/10.2105/AJPH.2004.050872

Kumar, S., Jeyaseelan, L., Suresh, S., \& Ahuja, R. C. (2005). Domestic violence and its mental health correlates in Indian women. British Journal of Psychiatry, 187(JULY), 62-67. https://doi.org/10.1192/bjp.187.1.62

Li, Y., Bloom, T., Herbell, K., \& Bullock, L. F. C. (2020). Prevalence and risk factors of intimate partner violence among Chinese immigrant women. Journal of Advanced Nursing, 76(10), 2559-2571. https://doi.org/10.1111/jan.14458

Malhotra, A., \& Mather, M. (1997). Do schooling and work empower women in developing countries? Gender and domestic decisions in Sri Lanka. Sociological Forum, 12(4), 599-630. https://doi.org/10.1023/A:1022126824127

Menon, S. (2020). The effect of marital endowments on domestic violence in India. Journal of Development Economics, 143(December 2018), 102389. https://doi.org/10.1016/j.jdeveco.2019.102389

NCRB. (2014). Crime Against Women. Retrieved from https://ncrb.gov.in/sites/default/files/crime_in_india_table_additional_table_chapter_rep orts/5-Crime against Women_2013.pdf

NCRB. (2019). Crime in India 2019. Retrieved from https://ncrb.gov.in/sites/default/files/CII 2019 Volume 1.pdf 
Pallikadavath, S., \& Bradley, T. (2019). Dowry, “dowry autonomy” and domestic violence among young married women in India. In Journal of Biosocial Science (Vol. 51). https://doi.org/10.1017/S0021932018000226

Panchanadeswaran, S., \& Koverola, C. (2005). The voices of battered women in India. Violence Against Women, 11(6), 736-758. https://doi.org/10.1177/1077801205276088

Panda, P., \& Agarwal, B. (2005). Marital violence, human development and women's property status in India. World Development, 33(5), 823-850. https://doi.org/10.1016/j.worlddev.2005.01.009

Priya, N., Abhishek, G., Ravi, V., Aarushi, K., Nizamuddin, K., Dhanashri, B., ... Sanjay, K. (2014). Masculinity, Intimate Partner Violence and Son Preference in India. In New Delhi, International Center for Research on Women (Vol. 4). Retrieved from http://www.esem.org.mk/en/pdf/Najznachajni vesti/2014/11/Masculinity Book_Inside_final_6th Nov.pdf

Purewal, N. (2018). Sex selective abortion, neoliberal patriarchy and structural violence in India. Feminist Review, 119(1), 20-38. https://doi.org/10.1057/s41305-018-0122-y

Ragavan, M., \& Iyengar, K. (2017). Violence Perpetrated by Mothers-in-Law in Northern India: Perceived Frequency, Acceptability, and Options for Survivors. Journal of Interpersonal Violence, 35(17-18), 3308-3330. https://doi.org/10.1177/0886260517708759

Rani, M., \& Bonu, S. (2009). Attitudes toward wife beating: A cross-country study in Asia. Journal of Interpersonal Violence, 24(8), 1371-1397. https://doi.org/10.1177/0886260508322182

Rao, V. (1997). Wife-beating in rural South India: A qualitative and econometric analysis. 
Social Science and Medicine, 44(8), 1169-1180. https://doi.org/10.1016/S02779536(96)00252-3

Rastogi, M., \& Therly, P. (2006). Dowry and its link to violence against women in India: Feminist psychological perspectives. Trauma, Violence, and Abuse, 7(1), 66-77. https://doi.org/10.1177/1524838005283927

Roy, S. (2015). Empowering women? Inheritance rights, female education and dowry payments in India. Journal of Development Economics, 114, 233-251. https://doi.org/10.1016/j.jdeveco.2014.12.010

Rudd, J. (2001). Dowry-murder: An example of violence against women. Women's Studies International Forum, 24(5), 513-522. https://doi.org/10.1016/S0277-5395(01)00196-0

Sabarwal, S., McCormick, M. C., Subramanian, S. V., \& Silverman, J. G. (2012). Son preference and intimate partner violence victimization in India: Examining the role of actual and desired family composition. Journal of Biosocial Science, 44(1), 43-56. https://doi.org/10.1017/S002193201100037X

Sahoo, H., \& Pradhan, M. R. (2009). Domestic violence in India: An empirical analysis. New Delhi: INDE: Serials, 89, 303-321. Retrieved from https://www.isical.ac.in/ wemp/Papers/PaperHariharSahooAndManasRanjanPradhan.pd $\mathrm{f}$

Sahoo, H., \& Raju, S. (2007). Domestic violence in India: Evidences and implications for working women. Social Change, 37(4), 131-152. https://doi.org/10.1177/004908570703700407

Sen, A. (2003). Missing women—revisited. Bmj, 327(7427), 1297-1298. https://doi.org/10.1136/bmj.327.7427.1297 
Sharma, B. R., Harish, D., Gupta, M., \& Singh, V. P. (2005). Dowry - A deep-rooted cause of violence against women in India. Medicine, Science and the Law, 45(2), 161-168. https://doi.org/10.1258/rsmmsl.45.2.161

Simister, J., \& Makowiec, J. (2008). Domestic violence in India: Effects of education. Indian Journal of Gender Studies, 15(3), 507-518. https://doi.org/10.1177/097152150801500304

Srinivasan, S., \& Bedi, A. S. (2007). Domestic Violence and Dowry: Evidence from a South Indian Village. World Development, 35(5), 857-880. https://doi.org/10.1016/j.worlddev.2006.08.005

Taft, C. T., Bryant-Davis, T., Woodward, H. E., Tillman, S., \& Torres, S. E. (2009). Intimate partner violence against African American women: An examination of the socio-cultural context. Aggression and Violent Behavior, 14(1), 50-58.

https://doi.org/10.1016/j.avb.2008.10.001

WHO. (2010). Preventing intimate partner and sexual violence against women: Taking action and generating evidence (Vol. 4). Retrieved from https://www.who.int/violence_injury_prevention/publications/violence/9789241564007 _eng.pdf

WHO. (2015). Consolidated guideline on sexual and reproductive health and rights of women living with HIV Executive summary. Retrieved from https://apps.who.int/iris/bitstream/handle/10665/254885/9789241549998-eng.pdf 
Table 1: Characteristics of married adolescent girls aged 15-19 years

\begin{tabular}{|c|c|c|}
\hline Background characteristics & Percentage & $\mathbf{N}$ \\
\hline \multicolumn{3}{|l|}{ Dowry demanded by husband } \\
\hline No & 74.1 & 3,678 \\
\hline Yes & 25.9 & 1,215 \\
\hline \multicolumn{3}{|l|}{ Perception over wife-beating } \\
\hline Not justified & 73.3 & 3,608 \\
\hline Justified & 26.7 & 1,285 \\
\hline \multicolumn{3}{|l|}{ Decision-making about her to work } \\
\hline Herself or Jointly with others & 53.5 & 2,652 \\
\hline Others Only & 46.5 & 2,241 \\
\hline \multicolumn{3}{|c|}{ Decision-making on household purchases } \\
\hline Herself or Jointly with others & 41.9 & 2,057 \\
\hline Others Only & 58.1 & 2,836 \\
\hline \multicolumn{3}{|l|}{ Paid work (last 12 months) } \\
\hline No & 88.9 & 4,361 \\
\hline Yes & 11.1 & 532 \\
\hline \multicolumn{3}{|l|}{ Marital duration (in years) } \\
\hline$\leq 1$ & 41.2 & 1,928 \\
\hline $2-3$ & 38.2 & 1,922 \\
\hline$\geq 4$ & 20.6 & 1,043 \\
\hline \multicolumn{3}{|l|}{ Age groups (in years) } \\
\hline $15-17$ & 26.6 & 1,271 \\
\hline $18-19$ & 73.4 & 3,622 \\
\hline \multicolumn{3}{|l|}{ Education level (in years) } \\
\hline No education & 27.3 & 1,365 \\
\hline 1-7 years & 23.5 & 1,112 \\
\hline 8-9 years & 25.0 & 1,214 \\
\hline $10 \&$ above & 24.2 & 1,202 \\
\hline \multicolumn{3}{|l|}{ Place of residence } \\
\hline Urban & 14.8 & 1,880 \\
\hline Rural & 85.2 & 3,013 \\
\hline \multicolumn{3}{|l|}{ Caste } \\
\hline SC/ST & 28.6 & 1,407 \\
\hline OBC & 60.7 & 2,978 \\
\hline Others & 10.6 & 508 \\
\hline \multicolumn{3}{|l|}{ Religion } \\
\hline Hindu & 84.1 & 4,097 \\
\hline Non-Hindu & 15.9 & 796 \\
\hline \multicolumn{3}{|l|}{ Wealth quintile } \\
\hline Poorest & 13.6 & 676 \\
\hline Poorer & 19.6 & 874 \\
\hline Middle & 23.4 & 1,069 \\
\hline Richer & 25.5 & 1,224 \\
\hline Richest & 17.9 & 1,050 \\
\hline \multicolumn{3}{|l|}{ State } \\
\hline Uttar Pradesh & 35.4 & 1,711 \\
\hline Bihar & 64.6 & 3,182 \\
\hline Total & 100.0 & 4893 \\
\hline
\end{tabular}

SC/ST: Scheduled Caste/Scheduled Tribe; OBC: Other Backward Class 
Table-2: Percentage distribution of type of violence among married adolescent girls aged 15-19 years

\begin{tabular}{|c|c|c|c|c|c|c|c|c|}
\hline \multirow[t]{2}{*}{ Background characteristics } & \multicolumn{2}{|c|}{ Emotional Violence } & \multicolumn{2}{|c|}{ Physical Violence } & \multicolumn{2}{|c|}{$\begin{array}{c}\text { Sexual } \\
\text { Violence }\end{array}$} & \multicolumn{2}{|c|}{$\begin{array}{c}\text { Any } \\
\text { Violence }\end{array}$} \\
\hline & Percentage & p-value & Percentage & p-value & Percentage & p-value & Percentage & p-value \\
\hline $\begin{array}{l}\text { Dowry demanded by } \\
\text { husband }\end{array}$ & & 0.000 & & 0.000 & & 0.000 & & 0.000 \\
\hline No & 19.7 & & 16.3 & & 21.4 & & 35.4 & \\
\hline Yes & 54.0 & & 42.1 & & 39.6 & & 68.4 & \\
\hline $\begin{array}{l}\text { Perception over wife- } \\
\text { beating }\end{array}$ & & 0.001 & & 0.000 & & 0.000 & & 0.000 \\
\hline Not justified & 26.5 & & 20.6 & & 22.4 & & 40.6 & \\
\hline Justified & 34.3 & & 29.5 & & 36.2 & & 53.3 & \\
\hline $\begin{array}{l}\text { Decision-making about her } \\
\text { to work }\end{array}$ & & 0.000 & & 0.612 & & 0.089 & & 0.000 \\
\hline Herself or Jointly with others & 32.6 & & 22.6 & & 27.6 & & 48.1 & \\
\hline Others Only & 24.0 & & 23.4 & & 24.3 & & 39.2 & \\
\hline $\begin{array}{l}\text { Decision-making on } \\
\text { household purchases }\end{array}$ & & 0.000 & & 0.135 & & 0.112 & & 0.000 \\
\hline Herself or Jointly with others & 34.7 & & 24.3 & & 28.1 & & 50.3 & \\
\hline Others Only & 24.2 & & 22.0 & & 24.6 & & 39.4 & \\
\hline Paid work (last 12 months) & & 0.392 & & 0.000 & & 0.001 & & 0.002 \\
\hline No & 28.3 & & 22.0 & & 25.2 & & 43.0 & \\
\hline Yes & 30.8 & & 30.5 & & 32.9 & & 51.4 & \\
\hline Marital duration (in years) & & 0.000 & & 0.000 & & 0.410 & & 0.000 \\
\hline$\leq 1$ & 17.8 & & 14.3 & & 25.3 & & 35.3 & \\
\hline $2-3$ & 30.2 & & 25.7 & & 25.8 & & 45.1 & \\
\hline$\geq 4$ & 47.3 & & 35.1 & & 28.3 & & 59.2 & \\
\hline Age groups (in years) & & 0.962 & & 0.008 & & 0.043 & & 0.987 \\
\hline $15-17$ & 28.5 & & 19.7 & & 28.9 & & 44.0 & \\
\hline $18-19$ & 28.6 & & 24.1 & & 25.1 & & 44.0 & \\
\hline Education level (in years) & & 0.000 & & 0.000 & & 0.000 & & 0.000 \\
\hline No education & 33.6 & & 30.4 & & 29.1 & & 48.4 & \\
\hline $1-7$ years & 33.3 & & 26.4 & & 29.3 & & 50.5 & \\
\hline
\end{tabular}




\begin{tabular}{|c|c|c|c|c|c|c|c|c|}
\hline $8-9$ years & 28.6 & & 21.8 & & 26.4 & & 44.0 & \\
\hline $10 \&$ above & 18.4 & & 12.4 & & 19.3 & & 32.6 & \\
\hline Place of residence & & 0.026 & & 0.700 & & 0.201 & & 0.045 \\
\hline Urban & 24.1 & & 22.3 & & 23.4 & & 39.3 & \\
\hline Rural & 29.4 & & 23.1 & & 26.6 & & 44.8 & \\
\hline Caste & & 0.000 & & 0.000 & & 0.000 & & 0.000 \\
\hline SC/ST & 31.4 & & 28.1 & & 32.4 & & 48.3 & \\
\hline $\mathrm{OBC}$ & 29.5 & & 22.0 & & 23.9 & & 44.2 & \\
\hline Others & 15.7 & & 14.1 & & 21.6 & & 30.7 & \\
\hline Religion & & 0.406 & & 0.328 & & 0.763 & & 0.936 \\
\hline Hindu & 29.0 & & 23.3 & & 26.2 & & 44 & \\
\hline Non-Hindu & 26.7 & & 21.2 & & 25.4 & & 43.8 & \\
\hline Wealth quintile & & 0.015 & & 0.000 & & 0.032 & & 0.001 \\
\hline Poorest & 32.0 & & 29.1 & & 30.4 & & 49.1 & \\
\hline Poorer & 31.8 & & 25.9 & & 28.4 & & 46.1 & \\
\hline Middle & 30.3 & & 25.5 & & 27.2 & & 46.3 & \\
\hline Richer & 27.8 & & 19.6 & & 24.1 & & 43.7 & \\
\hline Richest & 21.4 & & 16.5 & & 21.7 & & 35.0 & \\
\hline State & & 0.000 & & 0.024 & & 0.033 & & 0.000 \\
\hline Uttar Pradesh & 18.9 & & 20.2 & & 22.6 & & 36.9 & \\
\hline Bihar & 33.9 & & 24.5 & & 28.0 & & 47.9 & \\
\hline Total & 28.6 & & 22.9 & & 26.1 & & 44.0 & \\
\hline
\end{tabular}


Table-3. Estimates from logistic regression analysis for type of violence among married adolescent girls aged 15-19 years

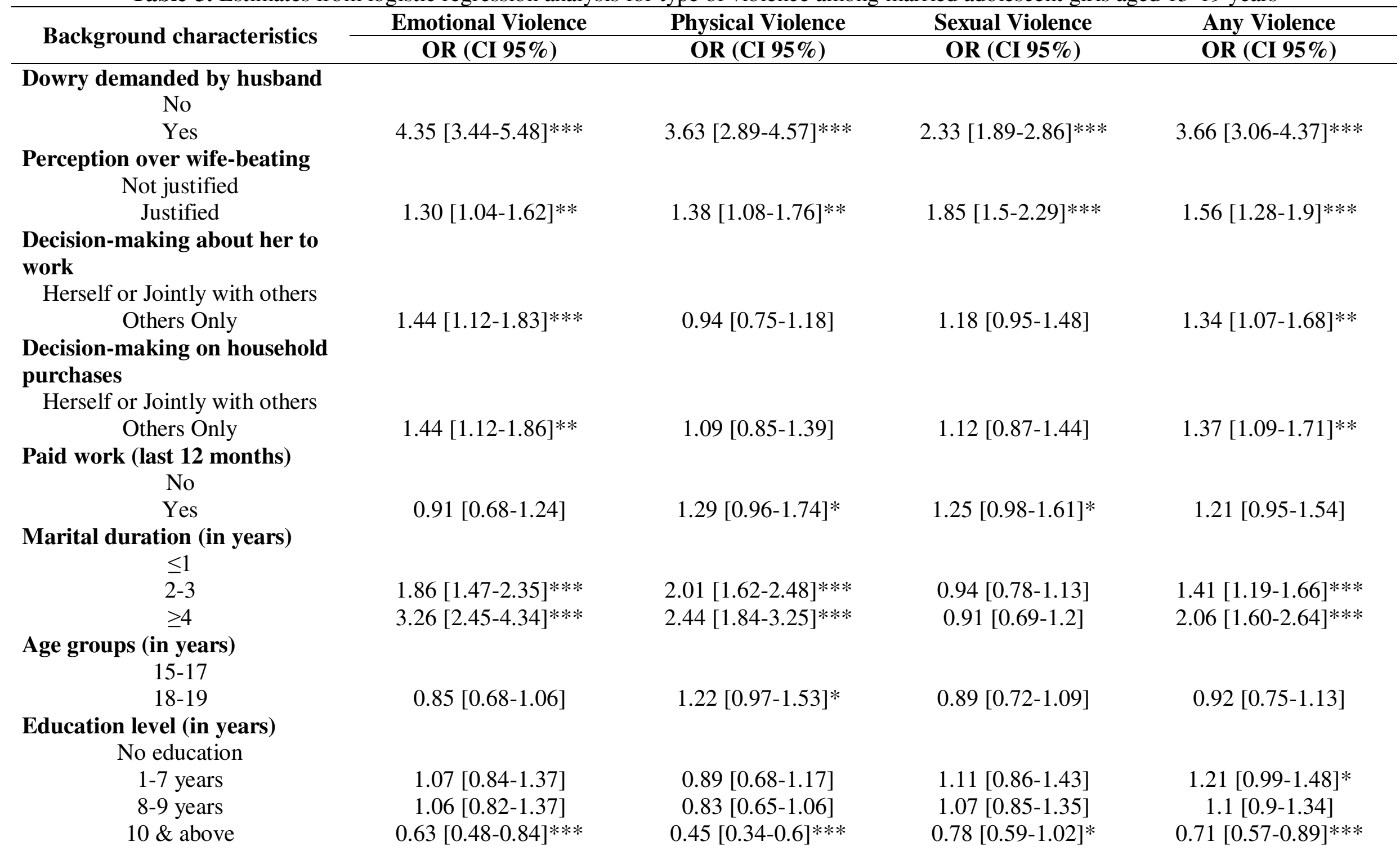


Place of residence

Urban

Rural

0.95 [0.75-1.19]

$0.8[0.63-1.03]^{*}$

$1.01[0.77-1.31]$

$1.02[0.82-1.27]$

Caste

SC/ST

OBC

Others

$$
0.92 \text { [0.75-1.13] }
$$

$0.78[0.62-0.98]^{* *}$

$0.58[0.39-0.85]^{* *}$

$0.68[0.53-0.87]^{* * *}$

0.69 [0.48-1]*

0.87 [0.72-1.06]

Religion

Hindu

Non-Hindu

1.17 [0.86-1.58]

0.97 [0.74-1.27]

1.14 [0.84-1.54]

1.22 [0.97-1.53]

Wealth quintile

Poorest

Poorer

$1.31[0.99-1.74] *$

1.24 [0.91-1.67]

Middle

1.04 [0.77-1.42]

Richer

0.99 [0.68-1.43]

1.06 [0.8-1.4]

$1.09[0.82-1.45]$

0.81 [0.56-1.17]

$-1.42]$

1.02 [0.74-1.4]

0.92 [0.65-1.29]

0.86 [0.6-1.25]

0.95 [0.66-1.37]

1.11 [0.84-1.47]

$1.16[0.87-1.56]$

1.05 [0.79-1.4]

State

Uttar Pradesh

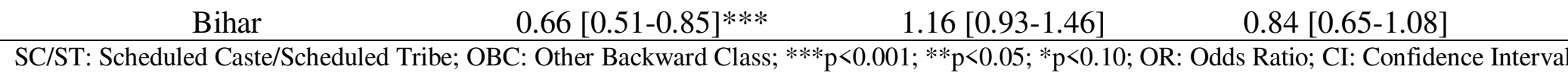

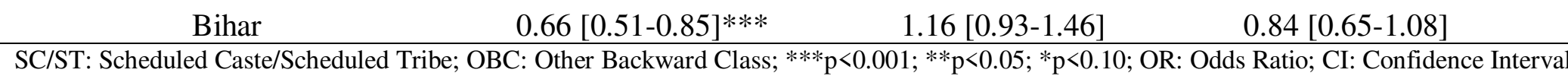

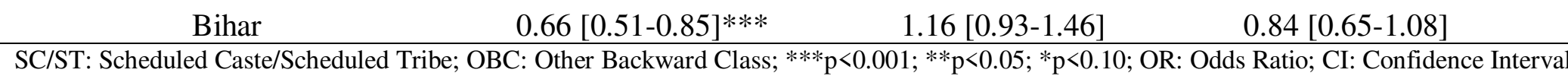

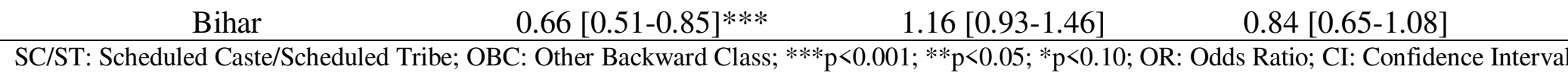

0.93 [0.67-1.29] 